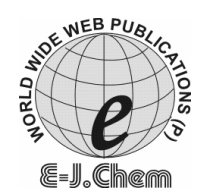

http://www.e-journals.net
ISSN: 0973-4945; CODEN ECJHAO

E-Journal of Chemistry

2008, 5(S2), 1149-1153

\title{
Development of RP-HPLC Method for the Estimation of Rabeprazole in Pure and Tablet Dosage Form
}

\author{
A.LAKSHMANA RAO*, B.N.V.RAVI KUMAR and G.G.SANKAR \\ Shri Vishnu College of Pharmacy, \\ Vishnupur, Bhimavaram-534 202, A.P., India. \\ lakshman1234@rediffmail.com
}

Received 18 March 2008; Accepted 10 May 2008

\begin{abstract}
A simple, rapid, sensitive and precise High Performance Liquid Chromatographic (HPLC) method has been developed for the estimation of rabeprazole in bulk and tablet dosage form. In this method $\mathrm{RP}_{-} \mathrm{C}_{18}$ column (150 $\mathrm{mm} \times 4.6 \mathrm{~mm}$ I.D, $5 \mu \mathrm{m}$ particle size) with mobile phase consisting of methanol and water in the ratio of $65: 35 \mathrm{v} / \mathrm{v}$ in isocratic mode was used. The detection wavelength is $284 \mathrm{~nm}$ and the flow rate is $0.8 \mathrm{~mL} / \mathrm{min}$. Tinidazole is used as internal standard. In the range of $0.25-20 \mu \mathrm{g} / \mathrm{mL}$, the linearity of rabeprazole shows a correlation coefficient of 0.9999 . The drug and internal standard were eluted at $4.41 \pm 0.05$ and $2.16 \pm 0.04 \mathrm{~min}$. respectively. The intra- and inter-day variation was found to be less than $1 \%$ showing high precision of the assay method. The detection limit was found to be $100 \mathrm{ng} / \mathrm{mL}$. The mobile phase selected for the proposed method is simple, fast, accurate and precise and hence can be applied for routine quality control analysis of rabeprazole in bulk and its tablet dosage form.
\end{abstract}

Keywords: Reverse phase HPLC, Rabeprazole sodium, Tinidazole

\section{Introduction}

Rabeprazole sodium (RBP) is a potent proton pump inhibitor ${ }^{1}$ that suppress gastric acid secretion by specific inhibition of the gastric $\mathrm{H}^{+}, \mathrm{K}^{+}$-ATPase enzyme system at the secretory surface of the gastric parietal cell and is used in the treatment of GERD ${ }^{2}$ and duodenal ulcers $^{3}$. It has a faster onset of action and lower potential for drug interaction compared to omeprazole. RBP is known chemically ${ }^{4}$ as 2-[[[4-(3-methoxypropoxy)-3-methyl-2pyridinyl]-methyl]sulfinyl]- $1 H$-benzimidazole sodium salt. Literature survey reveals that various HPLC methods ${ }^{5-12}$ and non-aqueous capillary electrophoresis method ${ }^{13}$ have been reported for the determination of rabeprazole in pharmaceutical dosage forms. The present method is simple, rapid, sensitive and precise HPLC method for the analysis of rabeprazole in bulk as well as in tablet dosage form. 


\section{Experimental}

\section{Materials}

Rabeprazole sodium was a gift sample from M/s Dr. Reddy's laboratories, Hyderabad, whereas tinidazole was from M/s Indu Drugs Ltd., Hyderabad. Methanol used was of HPLC grade (Emerck). The commercially available RBP procured from local market.

\section{Instrumentation}

Quantitative HPLC was performed on a gradient HPLC pump waters breez system with waters 1500 series HPLC pump, waters 2487 dual absorbance detector and $\mathrm{RP}_{-} \mathrm{C}_{18}$ column (150 mm $\times 4.6 \mathrm{~mm}$ I.D, $5 \mu \mathrm{m}$ particle size) was used. The HPLC system was equipped with Waters Breeze software.

\section{HPLC conditions}

The contents of the mobile phase were methanol: water in the ratio of $65: 35 \mathrm{v} / \mathrm{v}$ that were filtered through a $0.45 \mu \mathrm{m}$ membrane filter before use, degassed and pumped from the solvent reservoirs to the column at a flow rate of $0.8 \mathrm{~mL} / \mathrm{min}$. The run time was set at 6 minutes. The volume of injection loop was $20 \mu \mathrm{L}$ prior to injection of the drug solution the column was equilibrated for at least $30 \mathrm{~min}$. with the mobile phase flowing through the system. The eluents were monitored at $284 \mathrm{~nm}$.

\section{Procedure}

Stock solutions $(1 \mathrm{mg} / \mathrm{mL})$ of drug and internal standard were prepared by dissolving 100 $\mathrm{mg}$ of RBP and TNZ separately in $100 \mathrm{~mL}$ volumetric flasks containing $50 \mathrm{~mL}$ of water $(50 \mathrm{~mL}$ of methanol in the case of TNZ) and then made up the solution with respective solution up to the mark. Subsequent dilutions of this solution were made with mobile phase after addition of TNZ as an internal standard to get concentration of 0.25 to 20 $\mu \mathrm{g} / \mathrm{mL}$ of $\mathrm{RBP}$ and $4 \mu \mathrm{g} / \mathrm{mL}$ of internal standard in each dilution. The standard solutions prepared, as above, were injected triplicate into the column at flow rate of $0.8 \mathrm{~mL} / \mathrm{min}$. The ratio of drug peak area to that of internal standard was calculated. The regression of the drug concentration over the ratio of drug peak area to that of internal standard was obtained. This regression equation was used to estimate the amount of RBP in tablet dosage form. RBP solutions containing 4.6 and $10 \mu \mathrm{g} / \mathrm{mL}$ were subjected to the proposed HPLC analysis for finding out the intra and inter-day variations. The recovery studies were carried out by adding known amount of RBP to the preanalysed samples and subjecting them to the proposed HPLC method.

\section{Estimation of RBP in tablet dosage forms}

Twenty tablets were weighed and crushed to fine powder. An accurately weighed portion of the powder, equivalent to $25 \mathrm{mg}$ of active ingredient was taken and dissolved in water to get a solution of $1 \mathrm{mg} / \mathrm{mL}$ and filtered through $0.45 \mu \mathrm{m}$ membrane filter and further dilutions of this solutions were made with mobile phase after addition of TNZ to get concentrations of 0.25 to $20 \mu \mathrm{g} / \mathrm{mL}$ of RBP and $4 \mu \mathrm{g} / \mathrm{mL}$ of TNZ in each dilution. This solution $(20 \mu \mathrm{L})$ was injected in triplicate into the column. The mean values of peak area ratio of drug to internal standard of six such determinations were calculated and the drug content in the tablet was quantified using the regression equation obtained above. The same procedure was followed for the estimation of RBP in three different brands of tablet dosage forms. 


\section{Results and Discussion}

The present study was carried out to develop a sensitive, precise and accurate HPLC method for the analysis of RBP in bulk samples or pharmaceutical dosage forms. A typical chromatogram was shown in Figure 1.

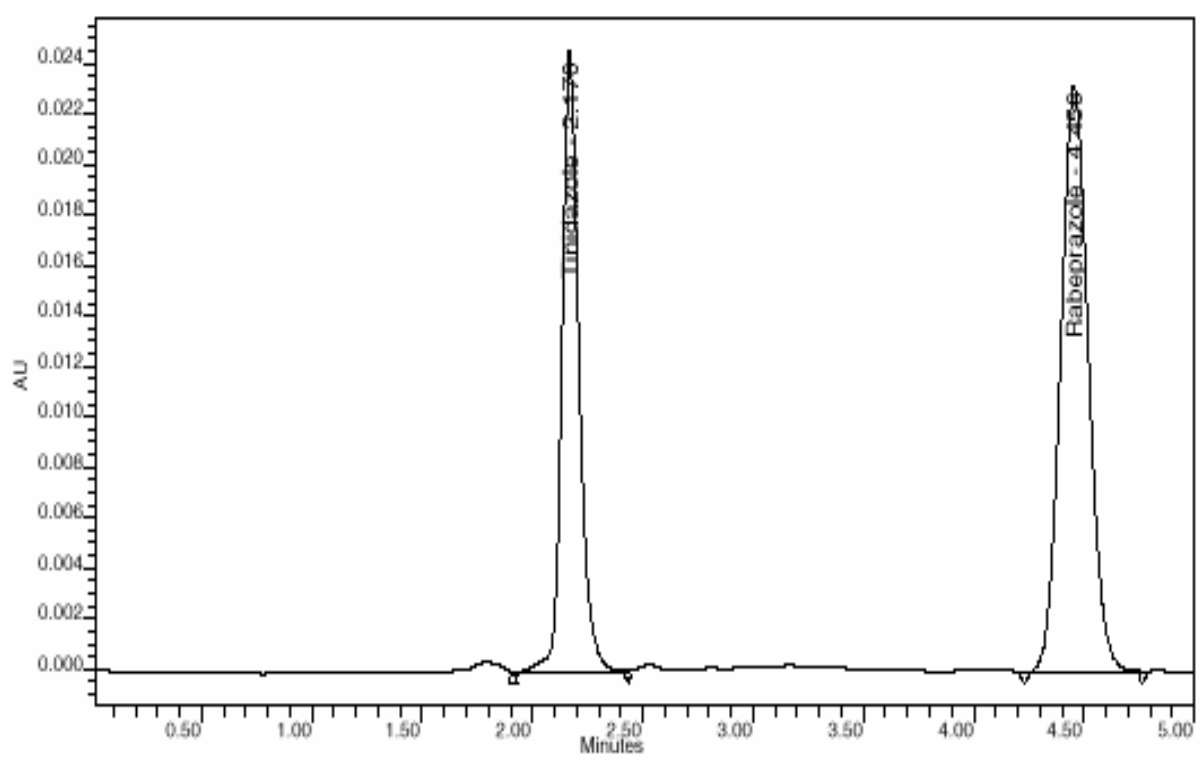

Figure 1. Typical chromatogram of rabeprazole

The retention times for RBP and internal standard were $4.41 \mathrm{~min}$ and $2.16 \mathrm{~min}$ respectively. The ratio of peak area of RBP to peak area of internal standard for different concentrations set up as above was calculated, and the average values for six such determinations were shown in Table 1. The peak areas of both the drug and internal standard were reproducible as indicated by low coefficient of variation (1.16). A good linear relationship $(r=0.9999)$ was observed between the concentration of RBP and the ratio of peak areas of the drug to that of internal standard. The calibration graph was found to be $\mathrm{Y}=0.0438+0.4788 \mathrm{X}$ (where $\mathrm{Y}=$ ratio of peak area of drug to that of internal standard; $\mathrm{X}=$ concentration of RBP) in the range of 0.25 to $20 \mu \mathrm{g} / \mathrm{mL}$. However, the lowest detection limit was found to be $100 \mathrm{ng} / \mathrm{mL}$ indicating a high sensitivity.

Table 1. Calibration of the proposed HPLC method

\begin{tabular}{ccc}
\hline $\begin{array}{c}\text { Concentration of RBP, } \\
\mu \mathrm{g} / \mathrm{mL}\end{array}$ & Mean peak area ratio & $\% \mathrm{CV}$ \\
\hline 0.1 & 0.0538 & 0.43 \\
0.25 & 0.1366 & 0.19 \\
0.5 & 0.2704 & 0.10 \\
1 & 0.5362 & 0.03 \\
2 & 0.9696 & 0.37 \\
4 & 1.9894 & 1.16 \\
6 & 2.9057 & 0.53 \\
10 & 4.8096 & 0.21 \\
20 & 9.4799 & 0.42 \\
\hline
\end{tabular}


When RBP solution containing $4 \mu \mathrm{g} / \mathrm{mL}, 6 \mu \mathrm{g} / \mathrm{mL}$ and $10 \mu \mathrm{g} / \mathrm{mL}$ were analysed by the proposed HPLC method for finding out intra- and inter-day variations, a low coefficient of variation was observed (Table 2). This shows that the present HPLC method is highly precise. Also when a known amount of the drug solution was added to the powdered sample of the tablet dosage form and subjected to the estimation of the drug by the proposed method, there was a high recovery to the estimation of the drug by the proposed method, there was a high recovery (Table 3 ) of RBP (100.45 \pm 0.92$)$ indicating that the proposed procedure for the determination of RBP in the tablet dosage forms is highly accurate.

Table 2. Inter and Intra day precision for RBP assay in pharmaceutical dosage form by the proposed HPLC method

\begin{tabular}{ccccc}
\hline \multirow{2}{*}{$\begin{array}{c}\text { Concentration } \\
\text { of RBP, } \\
\mu \mathrm{g} / \mathrm{mL}\end{array}$} & \multicolumn{2}{c}{ Observed concentration of RBP, $\mu \mathrm{g} / \mathrm{mL}$} \\
\cline { 2 - 5 } & \multicolumn{2}{c}{$\begin{array}{c}\text { Meantra day } \\
(\mathrm{n}=6)\end{array}$} & $\% \mathrm{CV}$ & \multicolumn{2}{c}{$\begin{array}{c}\text { Mean } \\
(\mathrm{n}=6)\end{array}$} & $\% \mathrm{CV}$ \\
\hline 4 & 4.06 & 0.23 & 3.95 & 0.43 \\
6 & 6.04 & 0.93 & 5.93 & 0.71 \\
10 & 10.05 & 0.75 & 9.92 & 0.31 \\
\hline
\end{tabular}

Table 3. Experimental values obtained in the recovery test for RBP tablets by proposed method

\begin{tabular}{ccccc}
\hline $\begin{array}{c}\text { Amount of drug } \\
\text { added }(\mu \mathrm{g}) \text { to drug } \\
\text { solution/powdered } \\
\text { tablet formulation }\end{array}$ & $\begin{array}{c}\text { Recovery from drug } \\
\text { solution }\end{array}$ & $\begin{array}{c}\text { Recovery from tablet } \\
\text { formulation }\end{array}$ \\
\cline { 2 - 5 } & $\begin{array}{c}\text { Mean amount } \\
\text { found }(\mathrm{n}=6)\end{array}$ & $\begin{array}{c}\text { Mean \% } \\
\text { recovery }(\mathrm{n}=6)\end{array}$ & $\begin{array}{c}\text { Mean amount } \\
\text { found }(\mathrm{n}=6)\end{array}$ & $\begin{array}{c}\text { Mean \% } \\
\text { recovery }(\mathrm{n}=6)\end{array}$ \\
\hline 2 & $2.03 \pm 0.22$ & $101.55 \pm 0.97$ & $1.99 \pm 0.19$ & $99.7 \pm 1.58$ \\
4 & $3.99 \pm 0.61$ & $99.95 \pm 1.33$ & $4.01 \pm 0.53$ & $100.45 \pm 0.92$ \\
6 & $6.07 \pm 0.40$ & $101.18 \pm 0.85$ & $5.97 \pm 0.37$ & $99.5 \pm 0.75$ \\
\hline
\end{tabular}

The drug content in the tablets was quantified using the proposed analytical method. The mean content of RBP in four different tablet dosage forms is shown in Table 4. The absence of additional peaks in test solution indicates no interference of the excipients used in the tablet dosage form. The low \% CV indicates the reproducibility of the assay of RBP in the tablet dosage form. The tablets were found to contain 99.5 to $103.9 \%$ of the labelled amounts.

Table 4. Mean amount of RBP in tablet dosage forms by proposed method

\begin{tabular}{cccc}
\hline Dosage form & $\begin{array}{c}\text { Labeled } \\
\text { amount, mg }\end{array}$ & $\begin{array}{c}\text { Observed } \\
\text { amount, mg }\end{array}$ & $\%$ purity \\
\hline A & 20 & $20.78 \pm 0.45$ & $103.9 \pm 0.20$ \\
B & 20 & $20.13 \pm 0.20$ & $100.6 \pm 0.13$ \\
C & 20 & $19.93 \pm 0.14$ & $99.65 \pm 0.70$ \\
D & 20 & $19.91 \pm 0.65$ & $99.55 \pm 0.53$ \\
\hline
\end{tabular}

\section{Conclusion}

The proposed HPLC method have been evaluated over the linearity, precision, accuracy, specify and proved to be convenient and effective for the quality control of rabeprazole in 
given application. The measured signal was shown to be precise, accurate and linear over the concentration range 0.25 to $20 \mu \mathrm{g} / \mathrm{mL}$ were tested with a correlation coefficient better than 0.9999 . The proposed method was further compared with an UV method reported by us and proved to be acceptable accuracy and precision. Moreover, the lower solvent consumption leads to a cost effective and environmentally friendly chromatographic procedure. Thus, the proposed HPLC method was found to be rapid, simple, precise, highly accurate, specific and less time consuming. Hence, it can be used for the routine determination of RBP in bulk and pharmaceutical dosage forms.

\section{Acknowledgements}

The authors gratefully acknowledge M/s Dr. Reddy's Laboratories, Hyderabad and M/s Indu Drugs Ltd., Hyderbad for providing the gift samples of Rabeprazole sodium and Tinidazole respectively.

\section{References}

1. Martindale, The Extra Pharmacopoeia, $3^{\text {rd }}$ Ed., The Royal Pharmaceutical Society, 1996, 1237.

2. Goodman and Gilman's, The Pharmacological Basis and Therapeutics, $10^{\text {th }}$ Ed., 2001, 1007.

3. Langtry H D and Markham A, Drugs, 1999, 58, 725-742.

4. The Merck Index, $12^{\text {th }}$ Ed., 1996, 1392.

5. Yun-Seok R, Chun-Woong P, Yoon-Sub S, Sung-Hoon K, Kyu-Hyun L and Eun-Seok P, Int J Pharm., 2008, 350, 122-129.

6. Cassia V G, Norma S N, Martin S and Elfrides E S S, J Pharm Biomed Anal., 2008, 46, 88-93.

7. Masatomo M, Hitoshi T, Shigeru S, Tomonori H and Toshio S, J Pharm Biomed Anal., 2006, 41, 565-570.

8. Mohammadi A, Haririan I, Rezanour N, Ghiasi L and Walker R B, J Chromatogr., A, 2006, 1116, 153-157.

9. Tsukasa U, Norio Y F, Mikiko S, Kazunobu S and Tomonori T, J Chromatogr., B, 2005, 824, 238-243.

10. Ramakrishna N V S, Vishwottam K N, Wishu S, Koteswara M and Kumar S S, J Chromatogr., B, 2005, 816, 209-214.

11. Alaa E G, Fawzy E Y and Moustafa M M, J Pharm Biomed Anal., 2003, 31, 229-242.

12. Nakai H, Shimamura Y, Kanazawa T, Yasuda S and Kayano M, J Chromatogr., $B$ Biomed Appl. 1994, 660, 211-220.

13. Tivesten A, Folestad S, Schonbacher V and Svensson K, Chromatographia., 1999, 49, S7-S11. 


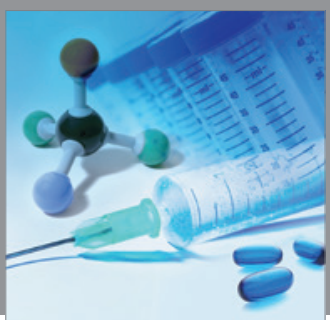

International Journal of

Medicinal Chemistry

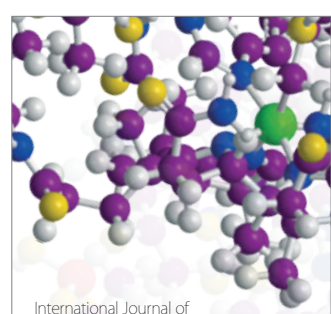

Carbohydrate Chemistry

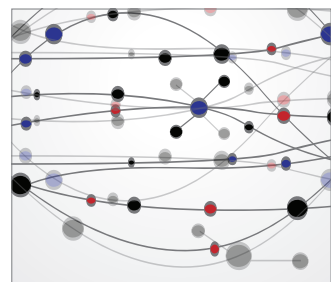

The Scientific World Journal
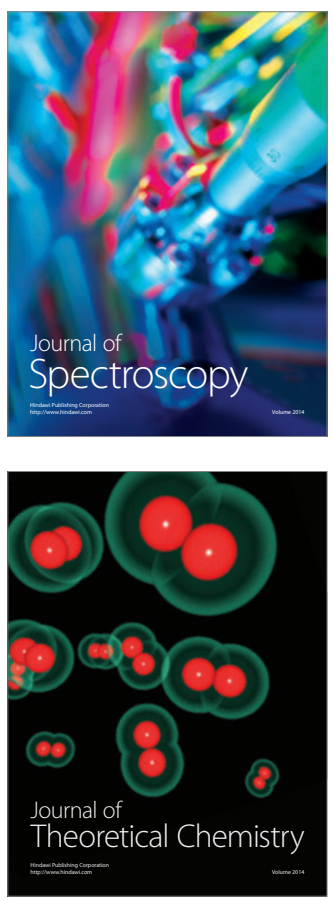
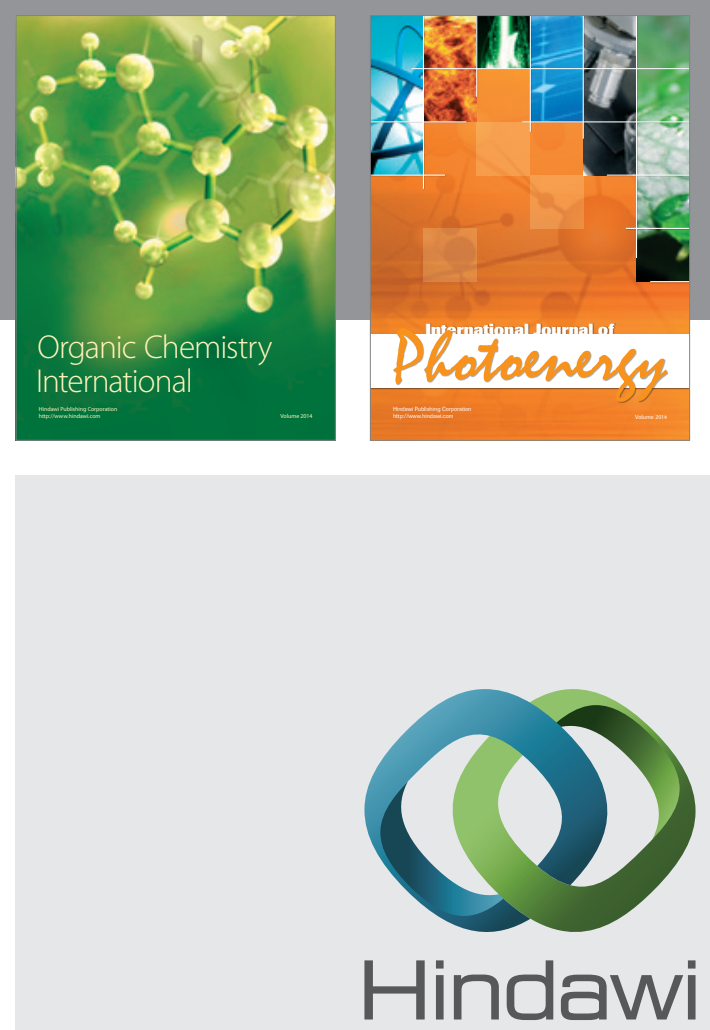

Submit your manuscripts at

http://www.hindawi.com
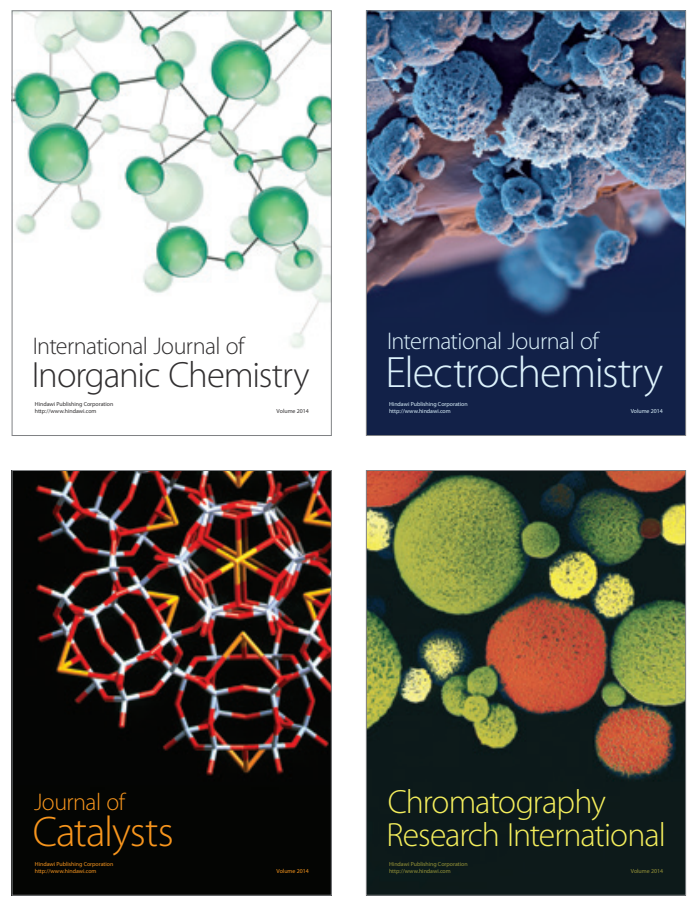
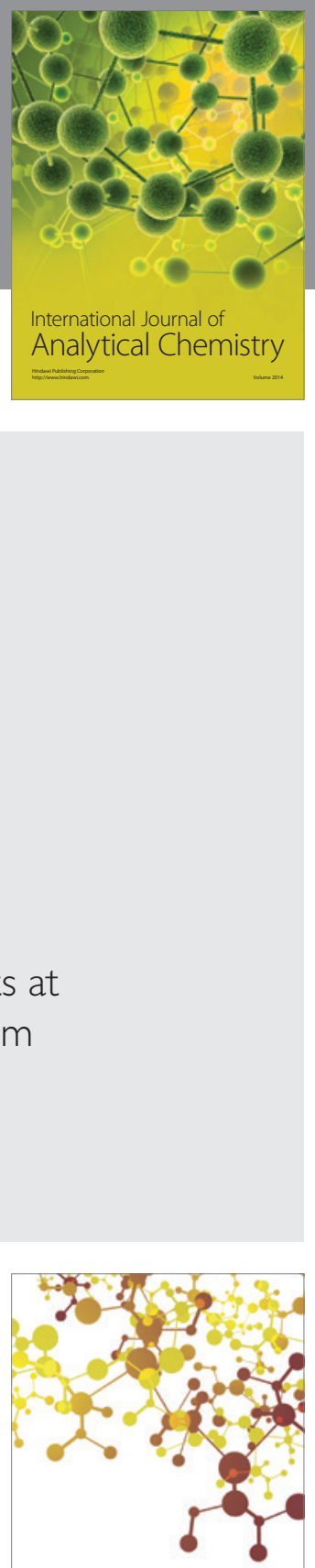

Journal of

Applied Chemistry
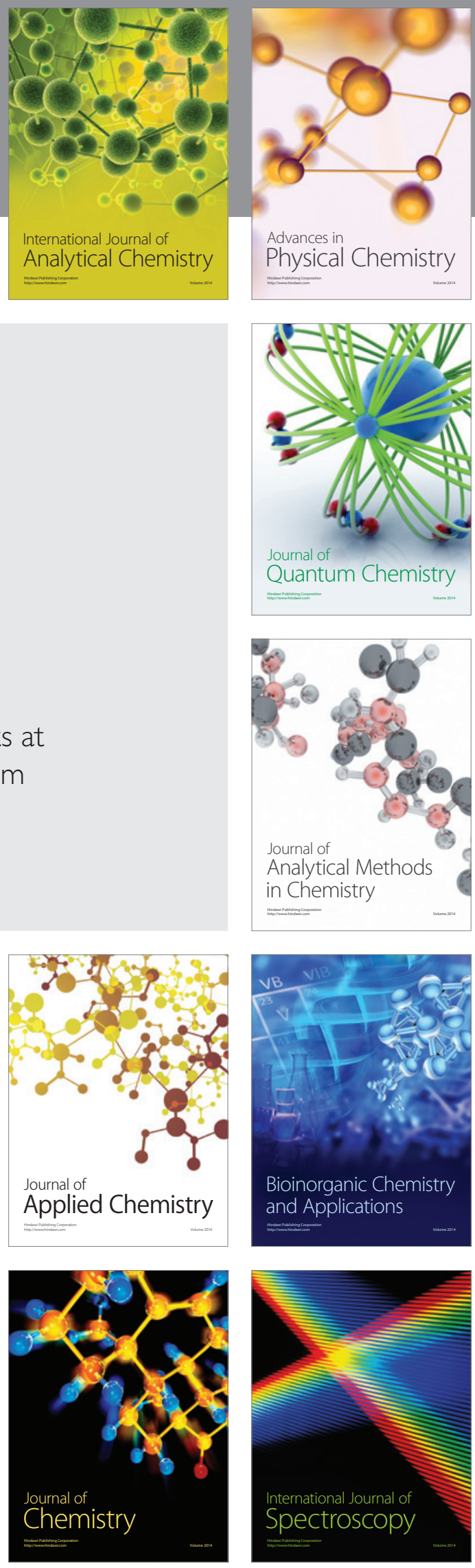